\title{
Nitrogen fixation by Oscillatoria spp. under autotrophic and photoheterotrophic conditions
}

\author{
John R. Gallon, ${ }^{*}$ M. Abul Hashem and Alan E. Chaplin \\ Biochemistry Research Group, School of Biological Sciences, University College of Swansea, Swansea SA2 8PP, UK
}

(Received II April 1990; revised 30 August 1990; accepted 24 September 1990)

\begin{abstract}
Oscillatoria spp. UCSB8 and UCSB25 are both capable of aerobic $\mathrm{N}_{2}$ fixation. The optimum temperature for $\mathrm{C}_{2} \mathrm{H}_{2}$ reduction was $22^{\circ} \mathrm{C}$ for Oscillatoria sp. UCSB8 and $35{ }^{\circ} \mathrm{C}$ for $O$ scillatoria sp. UCSB25, whilst the optimum temperature for growth on $\mathrm{N}_{2}$ was $25^{\circ} \mathrm{C}$ and $30^{\circ} \mathrm{C}$, respectively. In Oscillatoria sp. UCSB25, but not in UCSB8, inhibition of $\mathrm{N}_{2}$ fixation may limit diazotrophic growth at temperatures above $35^{\circ} \mathrm{C}$. When grown under alternating $12 \mathrm{~h}$ light and $12 \mathrm{~h}$ darkness, both isolates reduced $\mathrm{C}_{2} \mathrm{H}_{2}$ predominantly in the dark and both were capable of $\mathrm{N}_{2}$ fixation and photoheterotrophic growth in the presence of $20 \mu \mathrm{M}$-DCMU to inhibit photosystem II activity. Under these conditions, the best exogenous carbon source for Oscillatoria sp. UCSB8 was glucose, whilst that for Oscillatoria sp. UCSB25 was fructose. In Oscillatoria sp. UCSB8, exogenous glucose was catabolized mainly through the oxidative pentose phosphate pathway. Although cultures grown photoheterotrophically showed higher specific activities of nitrogenase than photoautotrophic cultures, they grew more slowly. Furthermore, cultures grown photoheterotrophically under alternating light and darkness reduced $\mathrm{C}_{2} \mathrm{H}_{2}$ both in the light and in the dark, but the highest rates of $\mathrm{C}_{2} \mathrm{H}_{2}$ reduction were observed in the dark. This cyclic pattern of $\mathrm{N}_{2}$ fixation was independent of photosystem II activity.
\end{abstract}

\section{Introduction}

Among cyanobacteria, aerobic $\mathrm{N}_{2}$ fixation is relatively rare except in those genera that produce heterocysts (Haselkorn, 1978; Wolk, 1982; Neuer et al., 1983). Nonheterocystous cyanobacteria that fix $\mathrm{N}_{2}$ aerobically fall into two groups: unicellular organisms such as Gloeothece (Wyatt \& Silvey, 1969; Gallon et al., 1988; Gallon \& Chaplin, 1988; Huang \& Chow, 1988; Gallon, 1989) and Synechococcus (Grobbelaar et al., 1986, 1987; Huang \& Chow, 1988; Mitsui et al., 1986, 1987; Spiller \& Shanmugan, 1987), and filamentous cyanobacteria such as Microcoleus chthonoplastes (Pearson et al., 1979; Malin \& Pearson, 1988) and Oscillatoria (Stal \& Krumbein, $1981,1985 a, b$; Khamees et al., 1987). In virtually all diazotrophic non-heterocystous cyanobacteria, the $\mathrm{O}_{2}$ sensitive nitrogenase complex seems to be located within the vegetative cell, together with the $\mathrm{O}_{2}$-evolving photosynthetic system. A possible exception to this is Trichodesmium (Oscillatoria) erythrea, in which $\mathrm{N}_{2}$ fixation may be confined to lightly pigmented cells located in the central region of bundles of individual

Abbreviation: DCMU, 3(3,4-dichlorophenyl)-1,1-dimethylurea. filaments (Carpenter \& Price, 1976; Bryceson \& Fay, 1981).

In all non-heterocystous cyanobacteria so far examined, except Trichodesmium (Bryceson \& Fay, 1981), $\mathrm{N}_{2}$ fixation occurred predominantly during the dark phase of an alternating cycle of light and darkness, thereby effecting a temporal separation between $\mathrm{N}_{2}$ fixation and oxygenic photosynthesis (Khamees et al., 1987). Under these conditions, ATP and reducing power for $\mathrm{N}_{2}$ fixation must be generated by dark metabolism. In Gloeothece, the ATP for $\mathrm{N}_{2}$ fixation may be provided by respiration rather than photosynthesis even under continuous illumination (Maryan et al., 1986). However, it is not clear whether this is the case in other nonheterocystous cyanobacteria. Furthermore, since Gloeothece does not grow on exogenously supplied sugars (Rippka et al., 1979) it has been impossible to examine the supply of energy and reductant to nitrogenase in the total, rather than temporal, absence of oxygenic photosynthesis. On the other hand, many Oscillatoria spp. can grow heterotrophically in the light when incubated with an inhibitor of photosynthesis and an appropriate sugar (Rippka et al., 1979) and, if capable of aerobic $\mathrm{N}_{2}$ fixation, should be more suitable organisms for such studies. In this paper, we describe some results on $\mathrm{N}_{2}$ 
fixation by two facultatively heterotrophic Oscillatoria spp. grown under photoautotrophic and photoheterotrophic conditions.

\section{Methods}

Isolation and growth of organisms. Oscillatoria sp. UCSB8 (University College of Swansea, Biochemistry Culture Collection) was isolated from Landimore Marsh, North Gower, close to Swansea (Griffiths et al., 1987). It was rendered unicyanobacterial by successive plating of gently homogenized cultures on the medium described by Khamees $e t$ al. (1987), solidified with $1 \%$ (w/v) Difco Bacto agar, followed by isolation of individual filaments. Homogenization was performed in a sterile Potter-Elvehjem glass homogenizer and served to disrupt cyanobacterial clumps into individual, undamaged trichomes. Unicyanobacterial cultures were treated with cycloheximide $\left(0 \cdot 1 \mathrm{mg} \mathrm{ml}^{-1}\right)$ to eliminate contaminating eukaryotes and were then freed from bacterial contamination on scored agar plates as described by Vaara $e t$ al. (1979). Cultures were routinely checked for contamination by microscopic examination of old cultures and by streaking on nutrient agar (Rippka et al., 1979). Large-scale cultivation of strain Oscillatoria sp. UCSB8 was performed at $22^{\circ} \mathrm{C}$ in 151 of the same medium as used for isolation, which is free of combined nitrogen and has an overall salinity approximately $50 \%$ that of seawater (Khamees et al., 1987). The light regime for growth was either continuous illumination or $12 \mathrm{~h}$ light $/ 12 \mathrm{~h}$ dark, with illumination $\left(25 \mu \mathrm{mol}\right.$ photons $\left.\mathrm{m}^{-2} \mathrm{~s}^{-1}\right)$ provided by Osram white fluorescent lights. All cultures were gassed continuously with air at $4.51 \mathrm{~min}^{-1}$. Alternatively, for growth experiments (see Table 4), cultures $(100 \mathrm{ml})$ were incubated in $250 \mathrm{ml}$ Erlenmeyer flasks on an orbital shaker at 120 oscillations $\mathrm{min}^{-1}$. Microscopic examination of Oscillatoria sp. UCSB8 revealed filaments of diameter $12 \mu \mathrm{m}$, composed of disc-shaped cells, 1-2 $\mu \mathrm{m}$ long.

Oscillatoria sp. UCSB25 was isolated from mangrove roots adjacent to Tickle Belly Creek, near Townsville, Queensland, Australia. Isolation was performed as described above, except that the medium contained $\left(\mathrm{mmol} \mathrm{l}^{-1}\right)$ : $\mathrm{NaCl}, 320 ; \mathrm{MgCl}_{2}, 18 \cdot 7 ; \mathrm{KCl}, 6 \cdot 7, \mathrm{CaCl}_{2}, 5 \cdot 9$; $\mathrm{NaHCO}_{3}, 1.8 ; \mathrm{Na}_{2} \mathrm{SO}_{4}, 0.9 ; \mathrm{KBr}, 0.6 ; \mathrm{H}_{3} \mathrm{BO}_{3}, 0.37 ; \mathrm{Na}_{2} \mathrm{CO}_{3}, 0.18 ;$ $\mathrm{MgSO}_{4}, 0.15 ; \mathrm{K}_{2} \mathrm{HPO}_{4}, 0.088 ; \mathrm{SrCl}_{2}, 0.067 ; \mathrm{NaF}, 0.048$; ferric citrate, $0.01 ; \mathrm{MnCl}_{2}, 0.009, \mathrm{Na}_{2} \mathrm{MoO}_{4}, 0.0016 ; \mathrm{MgNa}_{2} \mathrm{EDTA}, 0 \cdot 0012 ; \mathrm{ZnSO}_{4}$, $0.0008 ; \mathrm{CuSO}_{4}, 0.0003 ; \mathrm{CoCl}_{2}, 0.0002$. The $\mathrm{pH}$ was 8.0 and the salinity was approximately $75 \%$ that of seawater. For experimental purposes the culture volumes, light regime and air supply were identical to those described for Oscillatoria sp. UCSB8 (see above), but the temperature was $30^{\circ} \mathrm{C}$. Filaments of $O$ scillatoria sp. UCSB25 are composed of discshaped cells, approximately $3 \mu \mathrm{m}$ in width and $0.3 \mu \mathrm{m}$ in length.

For growth on combined nitrogen, $\mathrm{NaNO}_{3}(8 \mathrm{mM})$ was added to the media. For photoheterotrophic growth, the media were supplemented with $20 \mu \mathrm{M}$-DCMU. After autoclaving, filter-sterilized D-glucose, Dfructose or D-sucrose was added to a final concentration of $20 \mathrm{mM}$.

Immobilization of Oscillatoria spp. Immobilization of cultures of Oscillatoria in $0.5 \mathrm{~cm}$ diameter beads of calcium alginate was performed as described by Gallon et al. (1988). In order to avoid interference due to high salinity, cultures were suspended in nitrogenfree ASM-1 medium (Gallon et al., 1978) at a cell density equivalent to $0.5 \mathrm{mg}$ protein $\mathrm{ml}^{-1}$ and gently homogenized prior to immobilization. Immobilized cultures were then transferred to a bioreactor (Musgrave et al., 1982) containing $400 \mathrm{ml}$ of appropriate growth medium and aerated at $0.11 \mathrm{~min}^{-1}$. Alternatively, homogenized cultures were immobilized at approximately $0.1 \mathrm{mg}$ protein per cube in $0.125 \mathrm{~cm}^{3}$ cubes of polyvinyl foam, preincubated in appropriate growth medium (Gallon et al., 1988).

Photosynthetic and respiratory $\mathrm{O}_{2}$ exchange. $\mathrm{O}_{2}$ exchange was measured polarographically at $22^{\circ} \mathrm{C}$ (Oscillatoria sp. UCSB8) or $30^{\circ} \mathrm{C}$
(Oscillatoria sp. UCSB25), in the light $\left(25 \mu \mathrm{mol}\right.$ photons $\left.\mathrm{m}^{-2} \mathrm{~s}^{-1}\right)$ for net $\mathrm{O}_{2}$ production or in the dark for $\mathrm{O}_{2}$ consumption (Gallon \& Hamadi, 1984). In order to prevent cyanobacterial clumps from settling and interfering with efficient stirring during polarography, cultures were homogenized and immobilized in polyvinyl foam (see above) prior to transfer of five cubes to the $\mathrm{O}_{2}$ electrode vessel.

Evolution of ${ }^{14} \mathrm{CO}_{2}$. Cultures of Oscillatoria sp. UCSB8 $(100 \mathrm{ml})$ were transferred, 21-25 d after inoculation, to sterile Erlenmeyer flasks $(250 \mathrm{ml})$ which were then fitted with seals equipped with gas inlets and outlets. Prior to use, photoheterotrophically grown cultures were washed three times with fresh medium containing $20 \mu \mathrm{M}$-DCMU but no carbon source, and finally resuspended in $100 \mathrm{ml}$ of latter medium. By injection through the flask seal, $0.37 \mathrm{MBq}$ of either $\mathrm{D}-\left[1{ }^{14} \mathrm{C}\right] \mathrm{glucose}$ (2 TBq mol-1 ; Amersham) or D-[6-14 C]glucose (1.9 TBq mol-1 ${ }^{-1}$ New England Nuclear) was added to each culture. Each flask was then connected, in a fume cupboard, to a water-generated vacuum line such that the culture received a steady flow of air from the atmosphere at a rate of $50 \mathrm{ml} \mathrm{min} \mathrm{min}^{-1}$. For autotrophic cultures incubated with $\left[{ }^{14} \mathrm{C}\right]$ glucose in the light in the absence of DCMU, the air was supplemented with 0.01 atm $\mathrm{CO}_{2}$ in order to minimize refixation of ${ }^{14} \mathrm{CO}_{2}$. Before reaching the culture vessel, incoming air had been bubbled through a flask containing sterile distilled water, and after leaving the culture, the air passed through an ice trap and into a scintillation vial containing a mixture of $2 \mathrm{ml}$ ethanolamine and $8 \mathrm{ml}$ methanol. This mixture absorbed any ${ }^{14} \mathrm{CO}_{2}$ produced from the cyanobacterial culture. The air supply then passed through $0 \cdot 2 \mathrm{M}-\mathrm{KOH}$ as a safety precaution before reaching the vacuum pump. During incubation $\left(22^{\circ} \mathrm{C}\right)$, the cultures were gently stirred either in the dark or in the light $\left(25 \mu \mathrm{mol}\right.$ photons $\left.\mathrm{m}^{-2} \mathrm{~s}^{-1}\right)$. On each occasion, a culture was incubated with $\left[1^{-14} \mathrm{C}\right]$ glucose in parallel with an identical culture incubated with $\left[6-{ }^{-14} \mathrm{C}\right]$ glucose. No ${ }^{14} \mathrm{CO}_{2}$ was evolved from boiled cultures incubated with $\left[{ }^{14} \mathrm{C}\right]$ glucose.

After a suitable incubation period, air flow was temporarily interrupted. The scintillation vial was then removed and replaced by a fresh vial containing absorbant. The radioactivity in the removed vial was determined by liquid scintillation counting following addition of $10 \mathrm{ml}$ Emulsifier Scintillant 299 (Packard Instrument International).

Enzyme assays. Nitrogenase (EC 1 18.6.1) activity was measured by the $\mathrm{C}_{2} \mathrm{H}_{2}$ reduction technique (Tözüm et al., 1977). For some experiments (see Tables 2 and 3 ) aggregates of filaments were disrupted by gentle homogenization in a Potter-Elvehjem homogenizer to produce a uniform cell suspension prior to transfer to replicate assay flasks. To allow recovery of cultures from this treatment, assay flasks containing $50 \mathrm{ml}$ culture (about $2.5 \mathrm{mg}$ protein) were incubated for $48 \mathrm{~h}$ on an orbital shaker $\left(120\right.$ oscillations $\left.\mathrm{min}^{-1}\right)$ under identical conditions of temperature and illumination to those described for growth (see above). $\mathrm{C}_{2} \mathrm{H}_{2}$ was then added to a final concentration of $10 \%(\mathrm{v} / \mathrm{v})$ and $\mathrm{C}_{2} \mathrm{H}_{4}$ was monitored at hourly intervals. Nitrogenase activity in immobilized cultures was measured using 20 beads of calcium alginate (equivalent to about $1 \mathrm{mg}$ protein) suspended in $50 \mathrm{ml}$ fresh growth medium.

For experiments involving regular sampling of cultures over a period of up to $144 \mathrm{~h}$ (see Figs. 1 and 2), an alternative approach was adopted. The entire cultures were subjected to gentle homogenization $48 \mathrm{~h}$ prior to the start of the experiments and the uniform cell suspensions returned to the culture vessels. Although reaggregation of filaments occurred during the recovery period, no large clumps were formed. In order to take into account any variation in the number of cells present in individual samples removed from these cultures for experimental purposes, the protein content of each sample was measured.

Unless stated otherwise, Oscillatoria sp. UCSB8 was incubated at $22^{\circ} \mathrm{C}$ and Oscillatoria sp. UCSB 25 at $30^{\circ} \mathrm{C}$. For kinetic determinations, $\mathrm{C}_{2} \mathrm{H}_{2}$ was added at concentrations ranging between 0.0025 and 
$0 \cdot 1$ atm. In both strains of Oscillatoria, the apparent $K_{\mathrm{m}}$ for $\mathrm{C}_{2} \mathrm{H}_{2}$ was between 0.008 and $0.01 \mathrm{~atm}$.

The NADP+-dependent glucose-6-phosphate dehydrogenase (EC 1.1.1.49) of Oscillatoria UCSB8 was assayed spectrophotometrically at $340 \mathrm{~nm}$, using cell-free extracts prepared as described by Tözüm \& Gallon (1979). The reaction mixture $(2 \mathrm{ml})$ contained $20 \mathrm{~mm}$-HEPES/ $\mathrm{NaOH}$ buffer, pH 7.5, $2 \mathrm{~mm}-\mathrm{MgCl}_{2}, 0.1 \mathrm{~mm}-\mathrm{NADP}^{+}$and $0.5 \mathrm{ml}$ extract (equivalent to $1 \mathrm{mg}$ protein). The reaction was started by addition of $10 \mu \mathrm{mol}$ glucose 6-phosphate, sodium salt. Incubation was at $25^{\circ} \mathrm{C}$. The absorption change was corrected for that observed in the absence of glucose 6-phosphate, and for that obtained with boiled extracts.

Photosynthetic pigments. Photosynthetic pigments were estimated as described by Bennett \& Bogorad (1973).

Other measurements. Growth of cultures of Oscillatoria was estimated by measurement of their optical density at $436 \mathrm{~nm}$ (Fay et al., 1976), after homogenization (see above) to disrupt aggregated filaments. To avoid interference caused by changes in the intracellular concentration of photosynthetic pigments during growth of cultures, measurements were also made at $900 \mathrm{~nm}$. The doubling times calculated by measurements at $436 \mathrm{~nm}$ differed from those based on measurements at $900 \mathrm{~nm}$ by $7 \pm 1 \%$ (SEM; 135 determinations).

Dry weights were determined by filtration of cultures through a $0.2 \mu \mathrm{m}$ membrane (Millipore) followed by drying at $65^{\circ} \mathrm{C}$ until constant weight was achieved.

Protein was measured as described by Bailey (1962). In the case of cultures immobilized in polyvinyl foam, protein was first extracted at $55^{\circ} \mathrm{C}$ with $1 \mathrm{ml}$ per cube of $0.19 \mathrm{M}-\mathrm{Na}_{2} \mathrm{CO}_{3}$ in $0.1 \mathrm{M}-\mathrm{NaOH}$, as described by Price (1965). Blocks of foam containing no Oscillatoria served as reference samples.

\section{Results and Discussion}

As might be expected from the different temperature ranges encountered in their natural habitats, Oscillatoria sp. UCSB8, an isolate from a temperate region, reduced $\mathrm{C}_{2} \mathrm{H}_{2}$ maximally at $22^{\circ} \mathrm{C}$ whereas the tropical strain, Oscillatoria sp. UCSB25, showed optimum $\mathrm{C}_{2} \mathrm{H}_{2}$ reduction at $35^{\circ} \mathrm{C}$ (data not shown). Incubation at $15^{\circ} \mathrm{C}$ decreased maximal activity by about $50 \%$ in Oscillatoria sp. UCSB8 whilst a much more pronounced inhibition $(93 \%)$ was observed at this temperature in the tropical strain.

Optimum growth of Oscillatoria sp. UCSB8 on $\mathrm{N}_{2}$ occurred at $25^{\circ} \mathrm{C}$ whereas optimal growth rates for Oscillatoria sp. UCSB25 under these conditions were obtained at $30^{\circ} \mathrm{C}$ (Table 1). The temperature optima for growth on $\mathrm{N}_{2}$ of the two strains were therefore close to their optima for $\mathrm{C}_{2} \mathrm{H}_{2}$ reduction (see above). However, the two strains differed considerably in their response to temperature in the presence and absence of combined nitrogen (Table 1). The growth rates of Oscillatoria sp. UCSB8 were relatively similar under $\mathrm{N}_{2}$-fixing conditions and in $\mathrm{NO}_{3}^{-}$-containing medium at $22-30^{\circ} \mathrm{C}$. Above $30^{\circ} \mathrm{C}$, growth in the presence of $\mathrm{NO}_{3}^{-}$was completely arrested, whereas some residual growth was observed up to $40{ }^{\circ} \mathrm{C}$ with $\mathrm{N}_{2}$ as the source of nitrogen. In
Table 1. Growth of Oscillatoria spp. UCSB8 and UCSB25 at various temperatures

Replicate cultures, inoculated with a homogeneous cell suspension, were incubated in medium free of combined nitrogen or in medium containing $\mathrm{NaNO}_{3}$. At regular intervals during growth under continuous illumination, one of the replicate cultures was subjected to gentle homogenization to disrupt aggregates of filaments and its optical density measured at 436 and $900 \mathrm{~nm}$. The doubling times shown are based on measurements at $436 \mathrm{~nm}$ and are the means of at least four separate experiments $( \pm S D)$.

\begin{tabular}{|c|c|c|c|c|}
\hline \multirow{3}{*}{$\begin{array}{l}\text { Growth } \\
\text { temp. Nitrogen } \\
\left({ }^{\circ} \mathrm{C}\right) \text { source ... }\end{array}$} & \multicolumn{4}{|c|}{ Doubling time $(\mathrm{h})$} \\
\hline & \multicolumn{2}{|c|}{ UCSB8 } & \multicolumn{2}{|c|}{ UCSB25 } \\
\hline & $\mathrm{N}_{2}$ & $\mathrm{NO}_{3}^{-}$ & $\mathrm{N}_{2}$ & $\mathrm{NO}_{3}^{-}$ \\
\hline 15 & $283 \pm 11$ & ND & $1312 \pm 46$ & ND \\
\hline 20 & $255 \pm 9$ & ND & $715 \pm 28$ & ND \\
\hline 22 & $234 \pm 8$ & $202 \pm 10$ & ND & ND \\
\hline 25 & $201 \pm 6$ & $197 \pm 5$ & $211 \pm 7$ & $232 \pm 7$ \\
\hline 30 & $224 \pm 7$ & $200 \pm 5$ & $184 \pm 6$ & $197 \pm 6$ \\
\hline 35 & $498 \pm 25$ & $\infty$ & $203 \pm 8$ & $165 \pm 4$ \\
\hline 40 & $784 \pm 16$ & $\infty$ & $400 \pm 16$ & $160 \pm 5$ \\
\hline
\end{tabular}

$\infty$, No growth; ND, not determined.

contrast, growth of Oscillatoria sp. UCSB25 was similar on $\mathrm{N}_{2}$ and $\mathrm{NO}_{3}^{-}$at $25-30{ }^{\circ} \mathrm{C}$, but in the range of $35-40{ }^{\circ} \mathrm{C}$ there was a severe reduction of growth under $\mathrm{N}_{2}$-fixing conditions, whilst the presence of $\mathrm{NO}_{3}^{-}$in the medium stimulated growth at these temperatures. These results suggest that elevated temperatures $\left(30-40^{\circ} \mathrm{C}\right)$ affect not only $\mathrm{N}_{2}$ fixation but also general metabolism and cell function in Oscillatoria sp. UCSB8. In Oscillatoria sp. UCSB25, however, growth limitation under $\mathrm{N}_{2}$-fixing conditions above $35^{\circ} \mathrm{C}$ may result from a specific inhibition of $\mathrm{N}_{2}$ fixation.

Both species of Oscillatoria formed large aggregates of filaments during growth in liquid culture. Disruption of these aggregates by gentle homogenization did not destroy individual filaments, as judged by microscopic examination, but $\mathrm{N}_{2}$-fixing cultures treated in this way lost the ability to reduce $\mathrm{C}_{2} \mathrm{H}_{2}$. In Oscillatoria sp. UCSB8, this ability recovered during aerobic incubation more rapidly in standing cultures than in shaken cultures (Table 2). In each case, recovery coincided with reformation of aggregates. During microaerobic incubation under $\mathrm{N}_{2} / \mathrm{CO}_{2}(99 \cdot 97: 0 \cdot 03, \mathrm{v} / \mathrm{v})$ the lag period prior to recovery of $\mathrm{C}_{2} \mathrm{H}_{2}$ reduction was similar to that observed in aerobic cultures (Table 2), implying that aggregate formation did not provide $\mathrm{O}_{2}$-depleted microzones for optimum aerobic nitrogenase activity as may occur in other cyanobacteria (Paerl \& Carlton, 1988). Furthermore, immobilization of individual filaments of Oscillatoria sp. UCSB8 in beads of calcium alginate completely prevented any reaggregation, but the ability 
Table 2. Recovery of $\mathrm{C}, \mathrm{H}$, reduction by cultures of Oscillatoria sp. UCSB8 under different incubation conditions

Cells were collected from a batch culture, incubated under constant illumination, during the late exponential phase of growth (about $28 \mathrm{~d}$ after inoculation). Cultures designated as 'standing' or 'shaken' were gently homogenized to disrupt aggregates of filaments, after which replicate cultures were allowed to stand, or were shaken on an orbital shaker at 120 oscillations $\mathrm{min}^{-1}$, under constant illumination. The gas phase was either air or $\mathrm{N}_{2} / \mathrm{CO}_{2}$ $(99.97: 0.03, v / v)$. Immobilized cultures were generated by entrapping homogenized filaments in beads of calcium alginate (see Methods). At hourly intervals thereafter $\mathrm{C}_{2} \mathrm{H}_{2}$ reduction was measured in one of the replicate cultures. The lag periods quoted are those that preceded recovery and during which $\mathrm{C}_{2} \mathrm{H}_{2}$

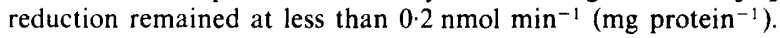
The values are the means of at least four separate experiments $( \pm \mathrm{SD})$.

\begin{tabular}{lccc}
\hline \hline & & \multicolumn{2}{c}{ Lag period (h) } \\
\cline { 3 - 4 } \multicolumn{1}{c}{ Incubation conditions } & $\begin{array}{c}\text { Gas } \\
\text { phase ... }\end{array}$ & Air & $\mathrm{N}_{2} / \mathrm{CO}_{2}$ \\
\hline Standing cultures & $14 \pm 4$ & $11 \pm 3$ \\
Shaken cultures & $34 \pm 2$ & $32 \pm 4$ \\
Standing immobilized cultures & $14 \pm 3$ & $\mathrm{ND}$ \\
\hline \hline
\end{tabular}

ND, Not determined.

to reduce $\mathrm{C}_{2} \mathrm{H}_{2}$ aerobically recovered as rapidly as in non-shaken unimmobilized cultures (Table 2). However, it may be argued that immobilization might affect parameters such as gas exchange or the level of illumination at filaments in the centre of each calcium alginate bead in a manner identical to that caused by aggregation. It therefore remains unclear whether aggregate formation is essential for aerobic $\mathrm{N}_{2}$ fixation by Oscillatoria spp., as seems to be the case in Trichodesmium erythrea (Bryceson \& Fay, 1981) but not in Trichodesmium sp. NIBB 1067 (Ohki \& Fujita, 1988). Nevertheless, it is possible that, as in Microcoleus chthonoplastes (Malin \& Pearson, 1988), aggregate formation in Oscillatoria spp. UCSB8 and UCSB25 is merely a typical property of filamentous cyanobacteria from benthic habitats whose beneficial effect is not linked to $\mathrm{N}_{2}$ fixation. Aggregation in such strains may, for example, limit desiccation during periods when the organisms are not submerged.

$\mathrm{C}_{2} \mathrm{H}_{2}$ reduction by Oscillatoria sp. UCSB8, grown photoautotrophically and assayed in the light, was stimulated (Table 3) in the presence of DCMU, an inhibitor of non-cyclic photosynthetic electron transport and $\mathrm{O}_{2}$ evolution. This is in agreement with the results of Stal \& Krumbein (1985b) for Oscillatoria strain 23, but contrasts with the observations on Gloeothece (Gallon, 1980) and Synechococcus (Grobbelaar et al., 1987), in which DCMU did not significantly alter nitrogenase activity. The stimulation of $\mathrm{C}_{2} \mathrm{H}_{2}$ reduction by DCMU
Table 3. Effect of DCMU and glucose on $\mathrm{C}_{2} \mathrm{H}_{2}$ reduction by Oscillatoria sp. UCSB8

Cells were collected from a batch culture, incubated under constant illumination, during the late exponential phase of growth (about $28 \mathrm{~d}$ after inoculation). Aggregates of filaments were disrupted by gentle homogenization and $50 \mathrm{ml}$ of the homogeneous cell suspension was then transferred to each assay flask. After $48 \mathrm{~h}$ under continuous illumination to allow recovery from this treatment, additions were made as indicated and after further incubation for the period shown, $\mathrm{C}_{2} \mathrm{H}_{2}$ was added to $10 \%(\mathrm{v} / \mathrm{v})$ and the rate of $\mathrm{C}_{2} \mathrm{H}_{2}$ reduction was measured over the following $60 \mathrm{~min}$. The rates of $\mathrm{C}_{2} \mathrm{H}_{2}$ reduction are the means of at least six observations; in parentheses these rates are expressed as percentages of the control culture without any addition.

\begin{tabular}{|c|c|c|}
\hline \multirow[b]{2}{*}{ Addition } & \multicolumn{2}{|c|}{$\begin{array}{c}\mathrm{C}_{2} \mathrm{H}_{2} \text { reduction } \\
{\left[\mathrm{nmol} \mathrm{min} \mathrm{m}^{-1}(\text { mg protein })^{-1}\right]} \\
\text { after incubation for: }\end{array}$} \\
\hline & $0 \mathrm{~h}$ & $3 \mathrm{~h}$ \\
\hline None & $2 \cdot 56(100)$ & $3.78(100)$ \\
\hline $20 \mu \mathrm{M}-\mathrm{DCMU}$ & $7 \cdot 73(302)$ & $15 \cdot 38(407)$ \\
\hline $20 \mu \mathrm{M}$-DCMU $+20 \mathrm{mM}$-glucose & $7.99(312)$ & $19 \cdot 50(516)$ \\
\hline $20 \mathrm{~mm}$-glucose & $2.59(101)$ & $6 \cdot 12(162)$ \\
\hline
\end{tabular}

may be a consequence of the inhibition of photosystem II activity, thereby decreasing the concentration of dissolved $\mathrm{O}_{2}$ in the vicinity of nitrogenase. If so, it would imply that, even in aggregates of Oscillatoria UCSB8, the protection of nitrogenase against $\mathrm{O}_{2}$ is not optimal and that photosynthetically generated $\mathrm{O}_{2}$ may inhibit $\mathrm{N}_{2}$ fixation substantially. Addition of $20 \mathrm{~mm}$-glucose enhanced $\mathrm{C}_{2} \mathrm{H}_{2}$ reduction in both the presence and absence of DCMU (Table 3), though only after a lag period, suggesting that this exogenously supplied carbohydrate might support $\mathrm{N}_{2}$ fixation. That this is the case was demonstrated by growth experiments (Table 4). Oscillatoria sp. UCSB8 grew photoheterotrophically under $\mathrm{N}_{2}$ fixing conditions on glucose, fructose or sucrose, though not on ribose or glycerol. Most rapid photoheterotrophic growth was found with glucose as carbon source, but growth was always slower than under photoautotrophic conditions. Oscillatoria sp. UCSB25 also grew photoheterotrophically in the absence of combined nitrogen (Table 4), but fructose was the preferred carbon source. Furthermore, the presence of an appropriate carbon source stimulated growth in the light, and also enabled both species of Oscillatoria to grow diazotrophically in the dark, though only very slowly.

When grown photoautotrophically under alternating $12 \mathrm{~h}$ light and $12 \mathrm{~h}$ darkness, Oscillatoria spp. UCSB8 (Fig. $1 a$ ) and UCSB25 (data not shown) fixed $\mathrm{N}_{2}$ predominantly during the period of darkness, with peak activities occurring 6-8 $\mathrm{h}$ after transfer to the dark. In this respect they resemble most other non-heterocystous cyanobacteria (see Introduction for references). Micro- 
Table 4. Growth of Oscillatoria spp. UCSB8 and UCSB25 under photoautotrophic, photoheterotrophic and chemoheterotrophic conditions

Replicate cultures, inoculated with a homogeneous cell suspension, were incubated at $22{ }^{\circ} \mathrm{C}$ (UCSB8) or $30^{\circ} \mathrm{C}$ (UCSB25) in continuous light, either with no additions or with $20 \mu \mathrm{M}$-DCMU (which completely inhibited photosynthetic $\mathrm{O}_{2}$ evolution), or in the dark. Where indicated, an organic carbon source was also present, at a concentration of $20 \mathrm{mM}$. At regular intervals during growth, one of the replicate cultures was subjected to gentle homogenization to disrupt aggregates of filaments, and its optical density measured at $436 \mathrm{~nm}$ and $900 \mathrm{~nm}$. The doubling times shown are based on measurements at $436 \mathrm{~nm}$ and are the means of at least four separate experiments $( \pm \mathrm{SD})$.

\begin{tabular}{llccc}
\hline \hline & & \multicolumn{3}{c}{ Doubling time (h) } \\
\cline { 3 - 5 } Strain & $\begin{array}{l}\text { Carbon } \\
\text { source }\end{array}$ & Light & $\begin{array}{c}\text { Incubation conditions: } \\
\text { Light + DCMU }\end{array}$ & Dark \\
\hline UCSB8 & None & $234 \pm 8$ & $\infty$ & $\infty$ \\
& Glucose & $180 \pm 8$ & $330 \pm 10$ & $1363 \pm 55$ \\
& Fructose & $210 \pm 14$ & $418 \pm 16$ & $\infty$ \\
& Sucrose & $249 \pm 10$ & $485 \pm 11$ & $2400 \pm 105$ \\
UCSB25 & None & $184 \pm 11$ & $\infty$ & $\infty$ \\
& Glucose & $146 \pm 5$ & $238 \pm 12$ & $\infty$ \\
& Fructose & $141 \pm 5$ & $178 \pm 8$ & $614 \pm 13$ \\
& Sucrose & $153 \pm 6$ & $258 \pm 5$ & $1032 \pm 38$ \\
\hline \hline
\end{tabular}

$\infty$, No growth.

scopic examination of Oscillatoria spp. UCSB8 and UCSB25 failed to identify any obviously differentiated cells, and it is possible that all cyanobacteria that fix $\mathrm{N}_{2}$ predominantly in the dark phase of an alternating cycle of light and darkness lack any spatial separation between $\mathrm{N}_{2}$ fixation and photosynthesis.

Photoheterotrophic cultures of Oscillatoria UCSB8 grown in an alternating cycle of $12 \mathrm{~h}$ light and $12 \mathrm{~h}$ darkness also reduced $\mathrm{C}_{2} \mathrm{H}_{2}$ predominantly in the dark but, unlike photoautotrophic cultures, showed significant, though decreasing with time, nitrogenase activity during the light phase (Fig. $1 b$ ). Furthermore, the maximum specific activities of $\mathrm{C}_{2} \mathrm{H}_{2}$ reduction during the dark phase of photoheterotrophic cultures were about 10 -fold greater than those of photoautotrophic cultures during the dark cycle (Fig. 1a), which may reflect the efficient use of exogenous glucose for $\mathrm{N}_{2}$ fixation. The persistence of significant levels of nitrogenase activity during the light phase of photoheterotrophic cultures (equivalent to those observed in photoautotrophic cultures during the dark phase) can be explained by the effect of DCMU on photosystem II activity, thus providing protection of nitrogenase against photosynthetically generated $\mathrm{O}_{2}$ (see above). However, the decrease of nitrogenase activities during the last few hours of the dark cycle and over the $12 \mathrm{~h}$ light period (Fig. $\mathrm{l} b$ ) is somewhat surprising, but it is clear that the cyclic pattern

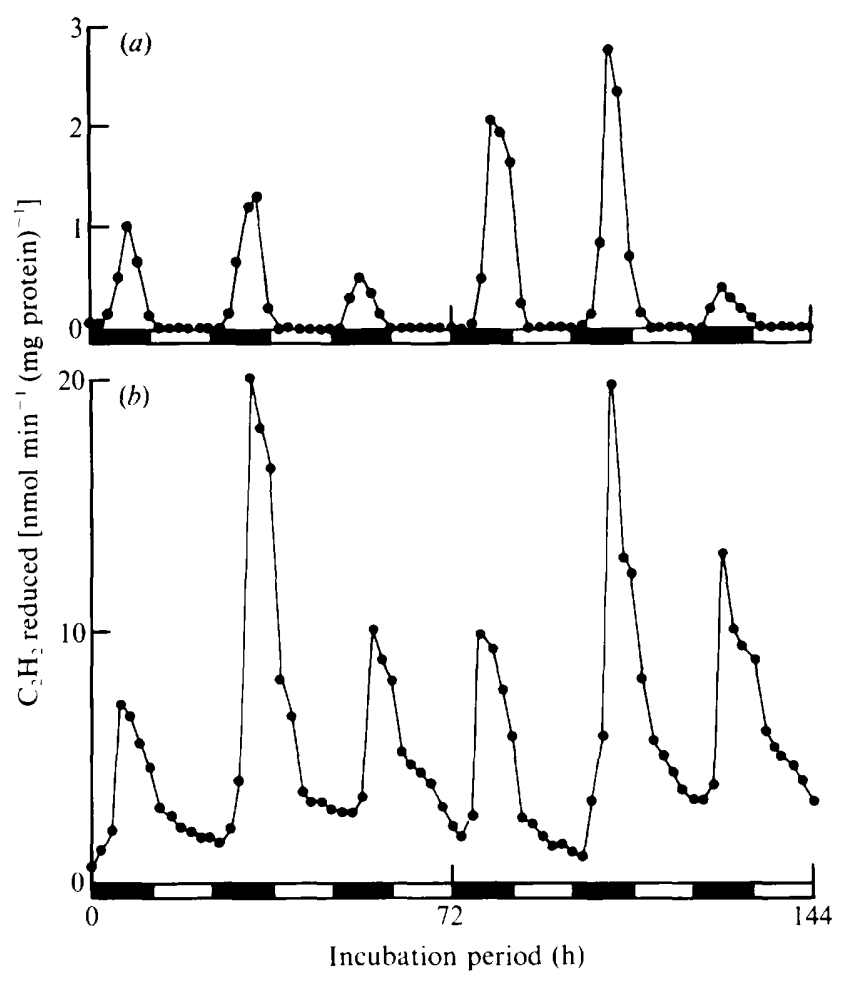

Fig. 1. $\mathrm{C}_{2} \mathrm{H}_{2}$ reduction by cultures of $O$ scillatoria sp. UCSB8 growing under alternating $12 \mathrm{~h}$ light and $12 \mathrm{~h}$ darkness $(a)$ photoautotrophically and $(b)$ photoheterotrophically in the presence of $20 \mu \mathrm{M}$-DCMU and $20 \mathrm{~mm}$-glucose. The data shown are from a single experiment but the observed fluctuations are typical (at least eight separate observations) of cultures grown under alternating light and darkness.

of nitrogenase activity imposed by this illumination regime is independent of photosystem II activity, which under these growth conditions is blocked by DCMU. In Gloeothece, the pattern of nitrogenase activity observed in photoautotrophic cultures under alternating light and darkness is achieved by regulation of nitrogenase synthesis (Gallon et al., 1988). This is dependent upon ATP, generated in the dark from breakdown of photosynthetically derived glucan, which may become limiting during the latter half of the dark phase. However, in photoheterotrophically grown cultures of Oscillatoria sp. UCSB8, exogenous glucose is available at all times during the light-dark cycle and therefore a limitation of carbon and energy is not to be expected during the dark phase and certainly cannot account for the decline of nitrogenase activity during the light period.

Under constant illumination, $\mathrm{C}_{2} \mathrm{H}_{2}$ reduction by Oscillatoria sp. UCSB8 showed peaks and troughs with successive troughs separated by about $120 \mathrm{~h}$ (Fig. $2 a$ ). These troughs coincided with periods of elevated net $\mathrm{O}_{2}$ evolution in the light (Fig. $2 b$ ) and with periods of relatively low rates of $\mathrm{O}_{2}$ consumption in the dark (Fig. 


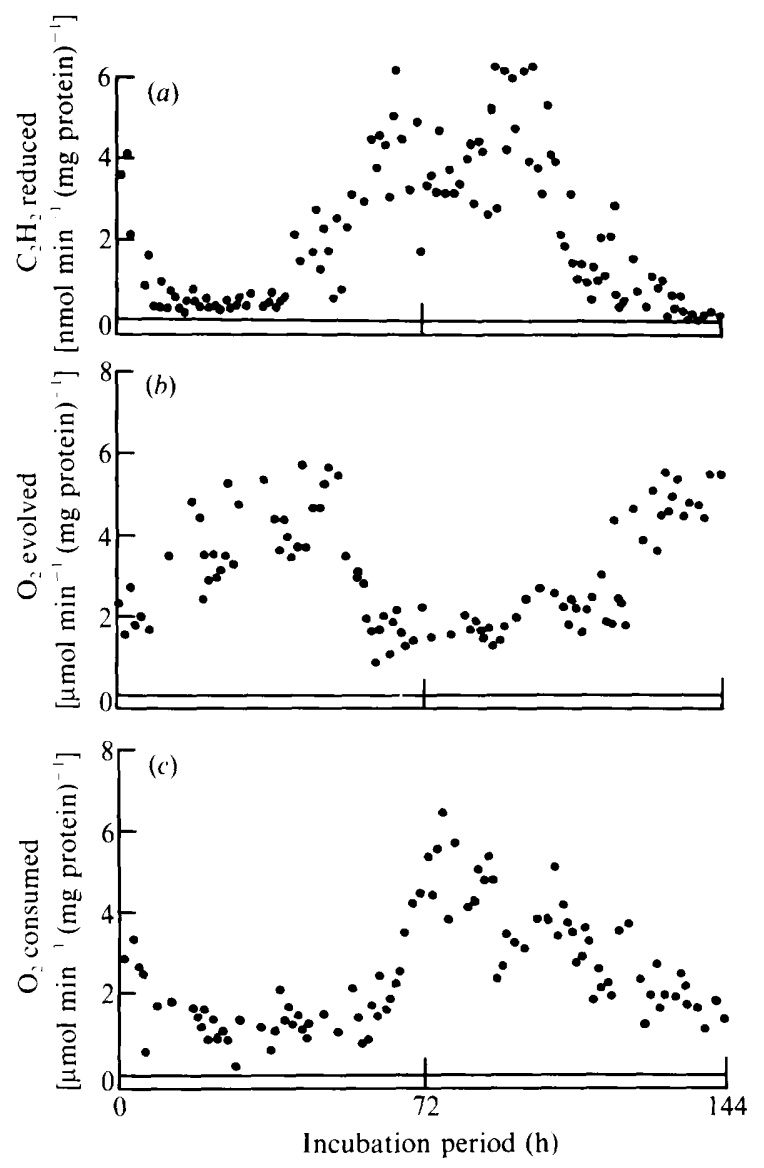

Fig. 2. $\mathrm{C}_{2} \mathrm{H}_{2}$ reduction (a), net $\mathrm{O}_{2}$ evolution measured in the light (b), and $\mathrm{O}_{2}$ consumption in the dark $(c)$ in cultures of Oscillatoria sp. UCSB8 incubated under continuous illumination. The data shown are from a single experiment but the observed fluctuations are typical (four separate observations) of cultures grown under constant illumination.

$2 c$ ). The relatively large fluctuations between some successive measurements resulted from the aggregation of the filaments during the course of the experiments, rendering homogeneous sampling for the assays difficult. Nevertheless, over and above these short-term fluctuations, there were distinct global changes in the rates of $\mathrm{C}_{2} \mathrm{H}_{2}$ reduction and $\mathrm{O}_{2}$ exchange during photoautotrophic growth of Oscillatoria sp. UCSB8 under continuous illumination. The interval (about $120 \mathrm{~h}$ ) that separated successive troughs in nitrogenase activity (Fig. $2 a$ ) is equivalent to about $50 \%$ of the doubling time of Oscillatoria sp. UCSB8 under these conditions (Table 4). This observation is in agreement with previous reports on the periodicity of nitrogenase activity under continuous illumination for Gloeothece (generation time 72 $80 \mathrm{~h}$, successive peaks or troughs of nitrogenase activity 30-40 h: Mullineaux et al., 1981) and for Oscillatoria sp. strain 23 (generation time $60 \mathrm{~h}$, intervals between peaks of nitrogenase activity about $24 \mathrm{~h}$ : Stal \& Krumbein, $1985 a$ ).
In photoheterotrophically grown cultures of Oscillatoria sp. UCSB8, the initial rate of ${ }^{14} \mathrm{CO}_{2}$ production was six- to seven-fold greater from $\left[1-{ }^{14} \mathrm{C}\right]$ glucose than from $\left[6-{ }^{14} \mathrm{C}\right]$ glucose (Table 5). This is consistent with the operation of the oxidative pentose phosphate pathway for glucose breakdown (Smith, 1982), and was observed in cultures grown photoheterotrophically or photoautotrophically, and incubated either in the light or in the dark (Table 5). It therefore appears that exogenous glucose is metabolized predominantly, if not exclusively, through the oxidative pentose phosphate pathway in both photoheterotrophically and photoautotrophically grown cultures of Oscillatoria sp. UCSB8. The activity of $\mathrm{NADP}^{+}$-dependent glucose-6-phosphate dehydrogenase, the first enzyme of the oxidative pentose phosphate pathway, was more than sevenfold greater in extracts of photoheterotrophic cultures of Oscillatoria sp. UCSB8

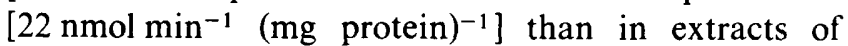

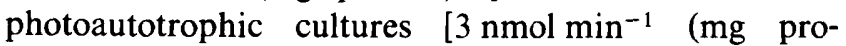
tein $)^{-1}$ ]. Furthermore, $\mathrm{O}_{2}$ consumption in the dark was greater $\left[10 \cdot 2 \mu \mathrm{mol} \mathrm{min}^{-1}\left(\mathrm{mg}\right.\right.$ protein $\left.\left.{ }^{-1}\right)\right]$ in photoheterotrophically grown cultures than in cultures grown photoautotrophically [ $\left.4.3 \mu \mathrm{mol} \mathrm{min}^{-1}\left(\mathrm{mg} \mathrm{protein}^{-1}\right)\right]$. In Oscillatoria sp. UCSB8, therefore, exogeneously supplied glucose, catabolized through the oxidative pentose phosphate pathway, can support $\mathrm{N}_{2}$ fixation. This implies that there is no obligatory link between photosynthesis and $\mathbf{N}_{2}$ fixation in this organism, and respiration rather than photosynthesis may support nitrogenase activity even under photoautotrophic conditions as has been reported for Gloeothece (Maryan et al., 1986). In agreement with this, photoautotrophically grown cultures of Oscillatoria sp. UCSB8, incubated under continuous illumination, showed peaks of nitrogenase activity coincident with low rates of $\mathrm{O}_{2}$ evolution in the light and maximum rates of $\mathrm{O}_{2}$ consumption in the dark (Fig. 2). Such a correlation has also been reported for Synechococcus spp. (Mitsui et al., 1987; Grobbelaar $e t$ al., 1987) but was not observed in Gloeothece (Gallon \& Chaplin, 1988; Gallon, 1989).

Both species of Oscillatoria appeared more pigmented under photoheterotrophic conditions than did photoautotrophically grown cultures. Expressed per unit dry weight, all of the photosynthetic pigments were more abundant in photoheterotrophically grown cultures of Oscillatoria sp. UCSB8 than in cultures grown photoautotrophically (Table 6). However, fluctuations in endogenous reserves of carbohydrates or in extracellular polysaccharides may distort data expressed per unit dry weight. On the basis of total protein, only phycoerythrin was more abundant in photoheterotrophic than in photoautotrophic cultures of Oscillatoria sp. UCSB8. In Oscillatoria UCSB25, phycocyanin per unit dry weight increased substantially in response to photoheterotro- 
Table 5. Evolution of ${ }^{14} \mathrm{CO}_{2}$ from $\left[1-{ }^{14} \mathrm{C}\right] \mathrm{glucose}$ and $\left[6-{ }^{-14} \mathrm{C}\right]$ glucose by cultures of Oscillatoria sp. UCSB8

Cultures of Oscillatoria sp. UCSB8, grown either photoautotrophically or photoheterotrophically (with $20 \mu \mathrm{M}$-DCMU and $20 \mathrm{~mm}$-glucose), were incubated with $0.37 \mathrm{MBq}$ of $\mathrm{D}-\left[1^{-14} \mathrm{C}\right]$ glucose or $\mathrm{D}-\left[6^{-14} \mathrm{C}\right]$ glucose. Production of ${ }^{14} \mathrm{CO}_{2}$ was measured during the following $6 \mathrm{~h}$. Cultures incubated in the light with $\left[{ }^{14} \mathrm{C}\right]$ glucose had previously been grown under constant illumination whilst cultures incubated in the dark had previously been grown under alternating light and darkness and were given $\left[{ }^{14} \mathrm{C}\right]$ glucose $3 \mathrm{~h}$ into the period of darkness. The rates of ${ }^{14} \mathrm{CO}_{2}$ evolution quoted represent initial rates and are the means of at least three separate experiments.

\begin{tabular}{|c|c|c|c|}
\hline \multirow[b]{2}{*}{$\begin{array}{l}\text { Growth and } \\
\text { assay conditions }\end{array}$} & \multicolumn{2}{|c|}{$\begin{array}{l}\text { Evolution of }{ }^{14} \mathrm{CO}_{2} \\
{\left[\mathrm{~Bq}(\mathrm{mg} \text { dry } \mathrm{wt})^{-1} \mathrm{~h}^{-1}\right]}\end{array}$} & \multirow{2}{*}{$\begin{array}{c}\text { Ratio of } \mathrm{CO}_{2} \\
\text { evolution } \\
{\left[1-1^{-14} \mathrm{C}\right] /\left[6^{-1+} \mathrm{C}\right]}\end{array}$} \\
\hline & $\begin{array}{r}\text { Subs } \\
{[1.14 \mathrm{C}] \text { Glucose }}\end{array}$ & $\begin{array}{l}\text { rate: } \\
{\left[6^{-14} \mathrm{C}\right] \text { Glucose }}\end{array}$ & \\
\hline \multicolumn{4}{|l|}{ Photoautotrophic } \\
\hline Light & $3 \cdot 3$ & $0 \cdot 5$ & $6 \cdot 6$ \\
\hline Dark & $5 \cdot 8$ & $1 \cdot 0$ & $5 \cdot 8$ \\
\hline \multicolumn{4}{|l|}{ Photoheterotrophic } \\
\hline Light & 7.9 & $1 \cdot 1$ & $7 \cdot 2$ \\
\hline Dark & $10 \cdot 0$ & $1 \cdot 6$ & $6 \cdot 3$ \\
\hline
\end{tabular}

Table 6. Pigment contents of photoautotrophic and photoheterotrophic cultures of Oscillatoria spp. UCSB8 and UCSB25

Batch cultures were grown for $28 \mathrm{~d}$ under continuous illumination at $22{ }^{\circ} \mathrm{C}$ (UCSB8) or $30^{\circ} \mathrm{C}$ (UCSB25). Photoheterotrophic growth was performed in the presence of $20 \mu \mathrm{M}$-DCMU and $20 \mathrm{~mm}$-glucose (UCSB8) or $20 \mathrm{~mm}$-fructose (UCSB25). Cultures were subjected to gentle homogenization prior to removal of samples for the determinations of dry weight, pigments and total protein. The data presented are the means of at least three determinations on separate cultures at the same stage of growth. Abbreviations: Chl $a$, chlorophyll $a$; PC, phycocyanin: APC, allophycocyanin; PE phycoerythrin.

\begin{tabular}{|c|c|c|c|c|}
\hline & \multicolumn{2}{|c|}{ UCSB8 } & \multicolumn{2}{|c|}{ UCSB 25} \\
\hline & $\begin{array}{l}\text { Photoauto- } \\
\text { trophic }\end{array}$ & $\begin{array}{l}\text { Photohetero- } \\
\text { trophic }\end{array}$ & $\begin{array}{l}\text { Photoauto- } \\
\text { trophic }\end{array}$ & $\begin{array}{l}\text { Photohetero- } \\
\text { trophic }\end{array}$ \\
\hline $\begin{array}{l}\text { Dry weight } \\
{\left[\mathrm{mg}(\mathrm{ml} \text { culture })^{-1}\right]}\end{array}$ & $1 \cdot 30$ & $1 \cdot 32$ & $1 \cdot 10$ & $1 \cdot 22$ \\
\hline $\begin{array}{l}\text { Protein } \\
{\left[\mu \mathrm{g}(\mathrm{mg} \text { dry } w t)^{-1}\right]}\end{array}$ & 158.4 & $312 \cdot 0$ & $161 \cdot 0$ & $244 \cdot 2$ \\
\hline $\begin{array}{r}\mathrm{Chl} a\left[\mu \mathrm{g}(\mathrm{mg} \text { dry wt })^{-1}\right] \\
{\left[\mu \mathrm{g}(\mathrm{mg} \text { protein })^{-1}\right]}\end{array}$ & $\begin{array}{c}3.4 \\
21.5\end{array}$ & $\begin{array}{r}5 \cdot 2 \\
16 \cdot 6\end{array}$ & $\begin{array}{r}4 \cdot 4 \\
27 \cdot 3\end{array}$ & $\begin{array}{r}5 \cdot 0 \\
20 \cdot 5\end{array}$ \\
\hline $\begin{array}{c}\mathrm{PC}\left[\mu \mathrm{g}(\mathrm{mg} \text { dry wt })^{-1}\right] \\
{\left[\mu \mathrm{g}(\mathrm{mg} \text { protein })^{-1}\right]}\end{array}$ & $\begin{array}{r}18 \cdot 6 \\
117 \cdot 4\end{array}$ & $\begin{array}{r}37 \cdot 8 \\
121 \cdot 2\end{array}$ & $\begin{array}{r}31 \cdot 4 \\
195 \cdot 0\end{array}$ & $\begin{array}{r}48 \cdot 0 \\
196 \cdot 6\end{array}$ \\
\hline $\begin{array}{l}\mathrm{APC}\left[\mu \mathrm{g}(\mathrm{mg} \text { dry wt })^{-1}\right] \\
{\left[\mu \mathrm{g}(\mathrm{mg} \text { protein })^{-1}\right]}\end{array}$ & $\begin{array}{r}18 \cdot 8 \\
118 \cdot 7\end{array}$ & $\begin{array}{l}30 \cdot 4 \\
97 \cdot 4\end{array}$ & $\begin{array}{r}17 \cdot 2 \\
106 \cdot 8\end{array}$ & $\begin{array}{l}18 \cdot 3 \\
74 \cdot 9\end{array}$ \\
\hline $\begin{array}{c}\mathrm{PE}\left[\mu \mathrm{g}(\mathrm{mg} \text { dry } w \mathrm{t})^{-1}\right] \\
{\left[\mu \mathrm{g}(\mathrm{mg} \text { protein })^{-1}\right]}\end{array}$ & $\begin{array}{l}10 \cdot 7 \\
67 \cdot 6\end{array}$ & $\begin{array}{r}54 \cdot 5 \\
174 \cdot 7\end{array}$ & $\begin{array}{r}4 \cdot 4 \\
27 \cdot 3\end{array}$ & $\begin{array}{r}3 \cdot 9 \\
16 \cdot 0\end{array}$ \\
\hline
\end{tabular}

phic growth, whereas the other photosynthetic pigments were relatively similar in concentration to those observed in photoautotrophic cultures. However, when expressed per unit of total protein, chlorophyll $a$, allophycocyanin and phycoerythrin decreased significantly in photo- heterotrophic cultures of Oscillatoria UCSB25, whilst the content of phycocyanin was similar to that observed in photoautotrophic cultures. Therefore, the visual changes of pigmentation of photoheterotrophic cultures of Oscillatoria UCSB8 are most likely due to an increase of 
phycoerythrin, whereas those observed in photoheterotrophic cultures of Oscillatoria UCSB25 are less readily evident, since neither chlorophyll $a$ nor total phycobiliprotein content increased per unit of total protein. In addition to their role as accessory photosynthetic pigments, the phycobiliproteins may function as nitrogen reserves (Carr, 1988). Photoheterotrophic $\mathrm{N}_{2}$-fixing cultures of Oscillatoria UCSB8 may be more nitrogenreplete than photoautotrophic cultures and thus synthesize more phycoerythrin, since the specific activities of nitrogenase were greater under photoheterotrophic conditions both under constant illumination (Table 3) and under alternating light and darkness (Fig. 1). Nevertheless, such cultures grew less rapidly than photoautotrophic cultures (Table 4), and some factor other than the rate of $\mathrm{N}_{2}$ fixation may limit growth under photoheterotrophic conditions.

In conclusion, it is proposed that in Oscillatoria sp. UCSB8, as in Gloeothece (Maryan et al., 1986) respiration may be more significant than photosynthesis itself in supporting $\mathrm{N}_{2}$ fixation. Respiration may be supported either by endogenous glucan reserves or by exogenously supplied glucose, fructose or sucrose, all of which are most likely metabolized via the oxidative pentose phosphate pathway. Although Oscillatoria sp. UCSB25 differs in some respects from Oscillatoria sp. UCSB8, it shares the ability to fix $\mathrm{N}_{2}$ photoheterotrophically and shows the same pattern of $\mathrm{N}_{2}$ fixation during growth under alternating light and darkness. The ability of these organisms to use exogenous carbon should prove useful for future investigations of the mechanisms involved in the regulation of both nitrogen and carbon metabolism in non-heterocystous diazotrophic cyanobacteria.

We thank the Association of Commonwealth Universities (UK) for the award of a scholarship to M.A.H., and Dr M.S.H. Griffiths for his valuable contribution to this work. We also acknowledge financial support from the Royal Society, and the skilled technical assistance of Mrs P.-A. Jones and Mr D. A. Jones.

\section{References}

Balley, J. L. (1962). Techniques in Protein Chemistry, p. 293. Amsterdam: Elsevier.

BENNETT, A. \& BogORAD, L. (1973). Complementary chromatic adaptation in a filamentous blue-green alga. Journal of Cell Biology $\mathbf{5 8}, 419-435$.

BRYCESON, I. \& FAY, P. (1981). Nitrogen fixation in Oscillatoria (Trichodesmium) erythrea in relation to bundle formation and trichome differentiation. Marine Biology 61, 159-166.

CARPenter, E. J. \& Price, C. C. (1976). Marine Oscillatoria (Trichodesmium): explanation for aerobic nitrogen fixation without heterocysts. Science 191, 1278-1280.

CARR, N. G. (1988). Nitrogen reserves and dynamic reservoirs in cyanobacteria. In Biochemistry of the Algae and Cyanobacteria, pp. 13-21. Edited by L. J. Rogers \& J. R. Gallon. Oxford: Oxford University Press.
FAY, R. H., Gibson, C. E. \& SMITH, R. V. (1976). The influence of day length, light intensity and temperature on the growth rates of planktonic blue-green algae. British Phycological Journal 11, 151-163.

Gallon, J. R. (1980). Nitrogen fixation by photoautotrophs. In Nitrogen Fixation, pp. 197-238. Edited by W. D. P. Stewart \& J. R. Gallon. London: Academic Press.

GalloN, J. R. (1989). The physiology and biochemistry of $N_{2}$ fixation by non-heterocystous cyanobacteria. Phykos 28, 18-46.

Gallon, J. R. \& Chaplin, A. E. (1988) Recent studies on $\mathrm{N}_{2}$ fixation by non-heterocystous cyanobacteria. In Proceedings of the 7 th International Congress on Nitrogen Fixation, pp. 183-188. Edited by H. Bothe, F. J. de Bruijn \& W. E. Newton. Stuttgart: Fischer.

Gallon, J. R. \& Hamadi, A. F. (1984). Studies on the effects of oxygen on acetylene reduction (nitrogen fixation) in Gloeothece sp. ATCC 27152. Journal of General Microbiology 130, 495-503.

Gallon, J. R., Ul-Haque, M. I. \& Chaplin, A. E. (1978). Fluoroacetate metabolism in Gloeocapsa sp. LB795 and its relationship to acetylene reduction (nitrogen fixation). Journal of General Microbiology 106, 329-336.

Gallon, J. R., Perry, S. M., Rajab, T. M. A., Flayeh, K. A. M., YUNES, J. S. \& ChAPLIN, A. E. (1988). Metabolic changes associated with the diurnal pattern of $\mathrm{N}_{2}$ fixation in Gloeothece. Journal of General Microbiology 134, 3079-3087.

Griffiths, M. S. H., Gallon, J. R. \& Chaplin, A. E. (1987). The diurnal pattern of dinitrogen fixation by cyanobacteria in situ. New Phytologist 107, 649-657.

Grobbelaar, N., Huang, T. C., Lin, H. Y. \& Chow, T. J. (1986). Dinitrogen-fixing endogenous rhythm in Synechococcus RF-1. FEMS Microbiology Letters 37, 173-177.

GrobbelaAR, N., LUN, H.-Y. \& Huang, T.-C. (1987). Induction of a nitrogenase activity rhythm in Synechococcus and the protection of its nitrogenase against photosynthetic oxygen. Current Microbiology 15, 29-33.

HASElkoRn, R. (1978). Heterocysts. Annual Review of Plant Physiology 29, 319-344.

Huang, T.-C. \& Chow, T.-J. (1988). Comparative studies of some nitrogen fixing unicellular cyanobacteria isolated from rice fields. Journal of General Microbiology 134, 3089-3097.

KhameEs, H. S., Gallon, J. R. \& Chaplin, A. E. (1987). The pattern of acetylene reduction by cyanobacteria grown under alternating light and darkness. British Phycological Journal 22, 55-60.

Malin, G. \& Pearson, H. W. (1988). Aerobic nitrogen fixation in aggregate forming cultures of the non-heterocystous cyanobacterium Microcoleus chthonoplastes. Journal of General Microbiology 134, 1755-1763.

Maryan, P. S., Eady, R. R., Chaplin, A. E. \& Gallon, J. R. (1986). Nitrogen fixation by Gloeothece sp. PCC 6090: respiration and not photosynthesis supports nitrogenase activity in the light. Journal of General Microbiology 132, 789-796.

Mitsui, A., Kumazawa, S., Takahashi, A., Ikemoto, H., Cao, S. \& ARAI, T. (1986). Strategy by which nitrogen-fixing unicellular cyanobacteria grow photoautotrophically. Nature, London 323,720 722.

Mitsui, A., Cao, S., Takahashi, A. \& Arai, T. (1987). Growth synchrony and cellular parameters of the unicellular nitrogen-fixing marine cyanobacterium, Synechococcus sp. strain Miami BG 043511 under continuous illumination. Physiologia Plantarum 69, 1-8.

MullineauX, P. M., Gallon, J. R. \& Chaplin, A. E.(1981). Acetylene reduction (nitrogen fixation) by cyanobacteria grown under alternating light-dark cycles. FEMS Microbiology Letters 10, 245-247.

Musgrave, S. C., Kerby, N. W., Codd, G. A. \& Stewart, W. D. P. (1982). Sustained ammonia production by immobilized filaments of the nitrogen-fixing cyanobacterium Anabaena 27893. Biotechnology Letters 4, 647-652.

Neuer, G., Papen, H. \& Bothe, H. (1983). Heterocyst biochemistry and differentiation. In Photosynthetic Prokaryotes, pp. 219-242. Edited by G. C. Papageorgiou \& L. Packer. New York: Elsevier.

OHKI, K. \& FuJITA, Y. (1988). Aerobic nitrogenase activity measured as acetylene reduction in the marine non-heterocystous cyanobacterium Trichodesmium spp. grown under artificial conditions. Marine Biology 98, 111-114. 
Paerl, H. W. \& Carlton, R. G. (1988). Control of nitrogen fixation by oxygen depletion in surface-associated microzones. Nature, London 332, 260-262.

Pearson, H. W., Howsley, R., Kueldsen, C. K. \& Walsby, A. E. (1979). Aerobic nitrogenase activity associated with a non-heterocystous filamentous cyanobacterium. FEMS Microbiology Letters 5, 163-167.

Price, C. A. (1965). A membrane method for determination of total protein in dilute algal suspensions. Analytical Biochemistry 12, 213 218.

Rippka, R., Deruelles, J., Waterbury, J. B., Herdman, M. \& StANIER, R. Y. (1979). Generic assignments, strain histories and properties of pure cultures of cyanobacteria. Journal of General Microbiology 111, 1-61.

SMITH, A. J. (1982). Modes of cyanobacterial carbon metabolism. In The Biology of Cyanobacteria, pp. 47-85. Edited by N. G. Carr \& B. A. Whitton, Oxford: Blackwell Scientific Publications.

Spiller, H. \& Shanmugam, K. T. (1987). Physiological conditions for nitrogen fixation in a unicellular marine cyanobacterium, Synechococcus sp. strain SF1. Journal of Bacteriology 169, 5379-5384.

Stal, L. J. \& Krumbein, W. E. (1981). Aerobic nitrogen fixation in pure cultures of benthic marine Oscillatoria (cyanobacteria). FEMS Microbiology Letters 11, 295-298.
Stal, L. J. \& Krumbein, W. E. (1985a). Nitrogenase activity in the non-heterocystous cyanobacterium Oscillatoria sp. grown under alternating light--dark cycles. Archives of Microbiology 143, 67-71.

Stal, L. J. \& Krumbein, W. E. (1985b). Oxygen protection of nitrogenase in the aerobically nitrogen fixing, non-heterocystous cyanobacterium Oscillatoria sp. Archives of Microbiology 143, 72-76.

TözÜM, S. R. D. \& GALLON, J. R. (1979). The effects of methyl viologen on Gloeocapsa sp. LB795 and their relationship to the inhibition of acetylene reduction (nitrogen fixation) by oxygen. Journal of General Microbiology 111, 313-326.

TözüM, D., Ul-Haque, M. I., Chaplin, A. E. \& Gallon, J. R. (1977). The effect of fluoroacetate on acetylene reduction by Gloeocapsa. Biochemical Society Transactions 5, 1482-1484.

Vaara, T., Vaara, M. \& Niemela, S. (1979). Two improved methods for obtaining axenic cultures of cyanobacteria. Applied and Environmental Microbiology 38, 1011-1014.

WoLK, C. P. (1982). Heterocysts. In The Biology of Cyanobacteria, pp. 359-386. Edited by N. G. Carr \& B. A. Whitton. Oxford: Blackwell Scientific Publications.

WyatT, J. T. \& Silvey, J. K. G. (1969). Nitrogen fixation by Gloeocapsa. Science 165, 908-909. 